\title{
The Red Queens of Restoration
}

\author{
Steven N. Handel
}

Now, here, you see, it takes all the running you can do, to keep in the same place. If you want to get somewhere else, you must run at least twice as fast as that!

(Dodgson, 1974)

T

The Red Queen hypothesis of evolution (Van Valen 1973), above, taken from the story of Alice Through the Looking Glass, states that one must move as fast just to stay in the same place. This is one of the foundations of understanding the power of genetic novelty, generating change that can lead to some selective advantage. If some species improve, and others around do not, then the ecological race is lost to the laggards. The rapid changers will usually win.

Does this evolutionary concept inform our restoration work? We feel there is a "full house" of Red Queens that all glare down at us as we work the land:

\section{The Red Queen of Biological Novelty}

Almost all habitats are being swept by new species introduced from other continents. Many of these species have very high population growth rates. These new-comers redefine our living communities and can have many effects on ecological function (Falk et al. 2006). Each of our projects is designed for now, but now is gone tomorrow in terms of the biotic crowd that we must confront. Each project must be designed, knowing that the background species assembly is rapidly changing. Can our restored community keep pace?

\section{The Red Queen of Physical Change}

Human actions continuously modify the physical environment upon which we work (Goudie 2000). On the small scale, soil chemistry and physical properties change with land-use and with deposition from the atmosphere upon which we act. The air itself has chemical components that change with the regional land uses. The heat load keeps rising, with atmospheric change and with hardscape, modifying the albedo of land. We may plant successfully for today's physical parameters, but next year and in 10 years and in 10 decades our plantings are in a new world of

Ecological Restoration Vol. 30, No. 1, 2012

ISSN 1522-4740 E-ISSN 1543-4079

(C2012 by the Board of Regents of the University of Wisconsin System. physical properties. Will they succeed? Will the restorationists who come after us be able to modify the original efforts quickly enough to respond to the new, imposed conditions?

\section{The Red Queen of Urbanization}

The human population is continually becoming more urban. More than half of the world's population now lives in urban centers, and the trajectory of future change is rising. Over $70 \%$ of humans will live in huge urban centers by the end of this century. This concentration of human energy, land uses, need for supplies, agriculture, waste areas, and vast infrastructure support networks will all impinge on the gentle restoration ecology work we are doing today. One can map and plan knowing where today's human footprint resides, put the urban Big Foot is bearing down. Can we determine where long-lived restoration projects should be placed by estimating the growth and direction of future urban centers? Does it pay to do small scale restoration near a city that is bursting with population growth?

There is a flipside to this worry, in those cities that are contracting because of social changes. Here more and more parcels are opening up which are not being used for social or economic means. Can we design nearby restored landscapes which have the ability to biologically spread and improve adjacent lands, which will soon be abandoned? Can we do this quickly enough to secure ecological services and to stop environmental degradation epidemics?

\section{The Red Queen of Institution Forgetfulness}

Political institutions change. Regulatory personnel move on. Public workforces are often too small, too overworked, too preoccupied with today's crises, and not with the tweaking and improvement of yesterday's efforts. There are almost no restoration projects which need zero management over the years. In the hundreds of restoration projects on public lands and administered by public entities, the small-scale and subtle changes that are required for ecological success are often lost in imperfect institutional structures. Can we design restored living communities that 
change for the better more quickly than the supervising agency fails to notice degradation?

\section{The Red Queen of Economic Distress}

Maybe this is a queen that will soon abdicate; we all hope so. But within a social environment where financial need has spread throughout the world, a focus on ecological structures and improvements, whose value will only be measured over the years, gets short shrift. Short-term gain seems so much more valuable when we start with so little. Can the wonderful enthusiasm and worldwide initiatives which have marked the last years of ecological restoration continue when so many eyes are focused on the wallet and not the landscape? Can the value of restoration be seen more quickly than we see the need for economic retrenchment?

Facing this cluster of queens is a royal pain. How simple would it be to do restoration ecology in a static world, where both the environment and human ecology remain the same! Success in our field has never been easy, but with all these changes crashing into the edges of our project sites, our planning and our efforts must keep one eye on the future, as well as one on the difficult now. The Red Queens must be engaged at each site for a realistic chance of winning our ecological restoration bets. Let's deal.

\section{References}

Dodgson, C.L. 1974. The Annotated Alice: Alice's Adventures in Wonderland \& Through the Looking Glass. New York, NY: New American Library.

Goudie, A. 2000. The Human Impact on the Natural Environment, 5th edition. Cambridge, MA: MIT Press.

Falk, D.A., M.A. Palmer and J.B. Zedler (eds). 2006. Foundations of Restoration Ecology. Washington DC: Island Press.

Van Valen, L.M. 1973. A new evolutionary law. Evolutionary Theory 1:1-30. 